\title{
A Bolshevized China- The World's Greatest Peril
}

\author{
ALSO
}

\section{NATIONALISTS' DELIBERATE POLICY ATTACKING ALL MISSIONS}

\section{CHINESE PASTOR STONED TO DEATH AT YOCHOW, HUNAN}

\author{
And other reprints from \\ . The "North-China Daily News" \\ And The "China Press" \\ Copies of this booklet may be obtained from \\ Edgar E. Strother, \\ 44 Nanking Road, \\ Shanghai
}

Contributions towards cost of printing and postage acceptable. 


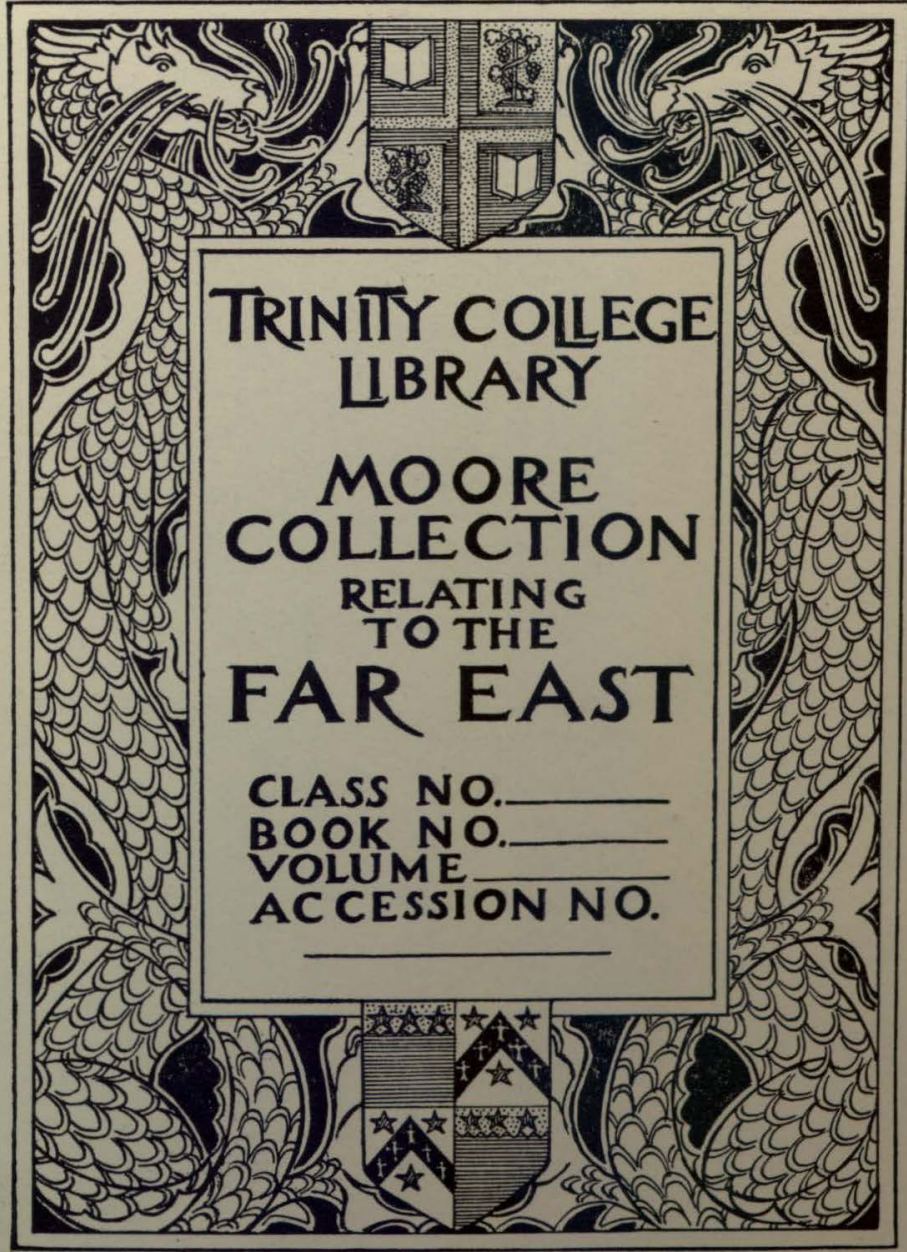




\section{CONTENTS.}

A Bolshevized China-The World's Greatest Peril ... .. 1

Nationalists' Deliberate Policy Attacking All Missions ... .. 4

Chinese Pastor Stoned To Death $\ldots \begin{array}{lllllllll} & \ldots & \ldots & \ldots & \ldots & \ldots & \ldots & 7\end{array}$

C.I.M. Premises At Anking $\begin{array}{llllllllllllll} & \ldots & \ldots & \ldots & \ldots & \ldots & \ldots & \ldots & \ldots & 9\end{array}$

Orgy of Mission Looting $\quad \ldots \begin{array}{lllllllllllll} & \ldots & \ldots & \ldots & \ldots & \ldots & \ldots & \ldots & \ldots & \ldots & 9\end{array}$

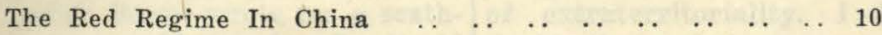

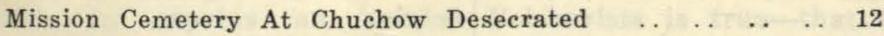

Semi-Nude Girls Are Following Communist Army .. . . . . 14

Naked Body Procession $\ldots \begin{array}{llllllllll} & \ldots & \ldots & \ldots & \ldots & \ldots & \ldots & \ldots & \ldots & 15\end{array}$

American's Testimony-Re Outrage Upon His Sister ... . 15

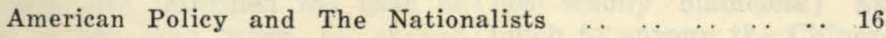

To the President \& People of the U.S.A.-Proposed Cablegram 17

Rodney Gilbert's Affidavit-Re Foreign Woman Raped Nine

Times by Nationalist Soldiers at Nanking $\ldots$.. $\quad . . \quad \ldots \quad 18$ 


\title{
A BOLSHEVIZED CHINA-THE WORLD'S GREATEST PERIL
}

\author{
The Persistent Propaganda Carried on by Missionaries in \\ America in Favour of the Reds: American \\ Public Thoroughly Deceived
}

By the Rev. Edgar E. Strother, General Secretary, China Christian Endeavour Union.

An article entitled "Is China Go- rising in China among the students ing Red?" which I prepared a as engineered largely by the couple of years ago was received Bolshevists and Soviet Russia, is with a good deal of eriticism by different from what comes to us editors and others in the homelands, from many of the missionaries, at as well as by many missionaries in least those who write for the Press, China who had not yet had their who think the uprising is due to the eyes opened to the subtle propaganda which was being carried on by the Soviet. The secretary of the Quaker Mission Board wrote me a scathing letter, asking why I should assume to express an opinion regarding conditions in China, when they were receiving their information from the National Christian Council, and especially from their own Dr. Henry T. Hodgkin, which contradicted all that I had written. He informed me that he was so provoked when he opened my letter and saw that I attributed the trouble in China to the influence of Bolshevism that he threw the letter into his waste paper basket, but later he decided to take it out and reply just to let me know how he felt about the matter and to advise me not to send any more of such unwelcome information to America. The events of recent months, especially the revelations in Peking since the raid of the Soviet premises there, have fully justified my statement.

The Other Missionary Point of View

A letter from the President of my own Mission Board, dated October 22,1925 , referred to my article as follows: "Your views of the upaggression of foreign countries and the injustices prepetrated by the restricted tariff laws and the matter of extraterritoriality. I have no doubt that what you say of the Bolshevists is true-that they are bitterly anti-Christian-but I am not sure that they are responsible for stirring up all the race trouble in China, for I think the foreign nations, with the exception perhaps of our own country (though that is not wholly blameless) have done much to enrage the Chinese. However, I know you are in a better position to judge than I."

A later letter from Dr. Clark, date January 18, 1926, says: "We are still hearing contradictory reports from China, some missionaries taking your view of the situation and others defending the students in all that they have done and blaming the commercial people for abuses which they think justify anything that the students may accomplish."

\section{Pro-Red Propaganda}

An article :n a recent number of the "Christian Endeavour World," entitled "The New China," is evidence of the effectiveness of the persistent propaganda carried on in 
America in favour of the Reds; it even justifies the Boxer uprising of 1900 in the following words: "China was then being prodded awake by the spears of the Boxers, justly aroused as they were by the aggressions of foreign nations and the insolent tyranny of foreign merchants and others." Then referring to the present upheaval, we read: "China for the Chinese is the cry of the Nationalists, who seem to be winning their way rapidly, so that they already have overrun more than half of China, have captured Hangchow, and have invested Shanghai itself. Who will say that it is an unworthy cry? For years and years China has belonged to any nation that might grab a piece of her territory. Great Britain, France, Germany, Spain, Italy, Japan, have all joined in this grab game. Foreigners residing in China for years have not been subject to her laws and courts, but to the laws and courts of their own countries. Nearly a score of such courts have been set up in Shanghai alone. This is what extraterritoriality means."

\section{The Nanking Outrages}

The American papers reported just after the Nanking outrage that "the British claim proof that the looting and murders at Nanking were done by Cantonese soldiers, etc.," regardless of the fact that it was not British but American missionaries from Nanking who testified to the fact that the outrage was committed by Southern soldiers, for the simple reason that there are only American missions in Nanking.

It is amazing to those of us who are familiar with the situation here in China to see how thoroughly the American public has been deceived as to the real facts. It is certainly evident that the Bolsheviks, with the effective aid of the so-called National Christian Council, have very nearly succeeded in pulling the wool over the eyes of the Americans. Evidence of this Red propaganda in the U.S.A. is now abundant. For example, in an interview, on his way from America, in Tokyo, the editor of the "Peking Leader," Mr. Grover Clark tells of his strenuous campaign of lectures in the principal cities of the United States for the Foreign Policy Association, and of his testimony before the Foreign Relations Committee of the Senate in Washington, in wrich he urged the revision of the unequal treaties, etc. Mr. Clark says he was twice in a motion picture theatre when films were shown of American marines landing in China, and that not a handelap greeted them, but that he overheard spectators say, "What right have our soldiers in China?" He asserts that no political party will dare to put a plank for a strong China policy in its platform for the 1928 campaign, because the public is almost unanimously against such a plank. It is very interesting to learn that in the raid of the Soviet premises in Peking, receipts for several hundred dollars a month were discovered, signed by Grover Clark, and it is said that one of these receipts bears the inquiry in $\mathrm{Mr}$. Clark's handwriting, "what about the $\$ 10,000.00$ ?"

\section{Mr. Millard's Writings}

Now comes the news to Shanghai that Dr. A. L. Warnshuis, formerly a secretary of the China Continuation Committee (the coconon out of which the N.C.C. was produced), but now in New York as a secretary of the International Missionary Council, together with a number of other former missionaries of the N.C.C. type, is praising the "New York World" because that paper has engaged Mr. Thomas F. Millard to write about the China situation and to "enable many of us to understand the present day movements in China and to keep in touch with them." An organization known as the American Committee for Justice to China issues the following statement: "Thomas F. Millard has be- 
gun sending weekly cables to the "New York World," appearing in its Monday editions; his despatches are the best appearing in America." Those of us who are familiar with the style of Mr. Millard's writings, in which he shows his "sympathy with the aspirations of the Chinese people and his understanding of the Chinese" and his exposure of the "evidence which has been accumulating of definite propaganda emanating from Shanghai to force the United States into aggressive action against China in partnership with Great Britain," have no difficulty in putting two and two together in this case.

\section{The Simple Truth}

Whether the American people desire to know it or not, the simple truth is that the upheaval in China is the direct result of propaganda directed and financed from Moscow, with a view to the Bolshevizing of the $400,000,000$ of Chinese, and the making of China the centre of the world-wide revolution, which is declared in their own documents to be the ultimate goal of the Communists. A Bolshevized China would be the world's greatest peril. It would not be very long before America would realize that her boasted isolation and independence is only an illusion, for the Bolsheviks' programme includes the overthrow of "this rotten Amercian Government," as soon as the British Government has been undermined.

Self-preservation is the first law of nature, and if the American people are not willing to realize that it is a great privilege to stand shoulder to shoulder with our British cousins and, in an unselfish spirit, restore order and peace in China and thus check the spread of Bolshevik madness in other countries, perhaps she will consider the fate which she herself will surely suffer in the near future if she continues to be blinded by the floods of red propaganda which are pouring into the United States, especial- ly aimed at the bringing about of an estrangement between our country and Great Britain, with whom we have more in common than with any other nation on earth.

\section{Dr. Sun And Bolshevism}

It is no use to say that China could not be Bolshevized. Dr. Sun Yat-sen said this to me, in an interview in his home in the French Concession, about 10 years ago, declaring that the Chinese farmers would never become Communists. But it was the Bolshevized Chinese farmers at Yochow, in Hunan province, only a few days ago, who took up stones and martyred the Chinese pastor who was putting up an official proclamation on the mission property, informing the public that the buildings should not be looted or burned. These Chinese farmers, who had been organized into a "Farmers" Labour Union" and taught the slogans of the Reds, called out that the Chinese Christian pastor was a "running dog of the Imperialists" and that he, therefore, ought to die, and they mercilessly stoned him to death.

The claim that a missionary is going into polities if he raises his voice in protest against Bolshevism is effectively answered by the statement that Bolshevism is primarily anti-Christian and aims at the stamping out of Christianity, and that, therefore, any missionary who declines to face this fact and to do all in his power to make it known to others is shirking his plain duty as a servant of Christ.

In my capacity as a missionary, and thinking primarily of the consequences to the Church of Christ thoughout the world if the mad dog of Bolshevism is not checked in China, but is allowed to jump across the seas to our own beloved America, I have no hesitation in asserting $\mathrm{my}$ conviction that $\mathrm{A}$ BOLSHEVIZED CHINA WOULD BE THE WORLD'S GREATEST PERIL. 


\title{
NATIONALISTS' DELIBERATE POLICY ATTACKING ALL MISSIONS
}

\author{
Wherever Southern Armies Have Gone Mission Premises \\ Looted or Seized for Barracks
}

\section{LITERALLY HUNDREDS THUS DESPOILED}

By LOUISE B. WILSON

At the present time when the question of future mission policies in China is being discussed by all mission offices, records are also being compiled by most of them regarding the extent of damage to their properties throughout China. The compilation is not anywhere near complete as can readily be understood in view of the proximity to recent events in Central China, as well as the uncertainties attached to evacuated places many of which require weeks for communications to reach.

In most cases there is no hesitation on the part of foreign missionaries to admit that these inventories are being prepared with a view to securing reparations. Others are not yet willing to commit themselves as to whether this is the end in view or not. The former group, however declare that they find in the present situation few points of comparison with past, and from the point of view of destructive elements, similar incidents. The present is an organized movement whereas in the past, should reparations have been demanded, payments would only have been extracted from Chinese communities in the vicinity of the destroyed mission, an extraction which would scarcely have tended to cement the Christian movement in those communities.
The stewards of foreign money and properties are thus beginning to trace the lines of contrast with past happenings. They realize that, while the very nature of missionary work implies sacrifice and exigencies not considered perhaps by those outside evangelistic work, the organized forces at work in the present movement, though displaying some of the ruthless tendencies not unknown in the past throw an altogether different aspect upon the present.

No honest mission worker will tell you that the eventual hope of his mission is anything other than turning over all institutions, schools, etc., to the Chinese Christians. But that again is a slightly different matter from being forcibly ejected from residences by anti-foreign soldiers, from seeing churches used as stables, and modern, splendidly equipped hospitals used as barracks for a filthy horde and a general disregard of law and order in its most lenient sense, not to mention the finer distinctions of property rights.

As in all such cases, however, the thing to do is to let facts speak for themselves. Such facts mount to an over-awing accumulation for him who would present them one by one, and as has already been said mission officers are not themselves fully prepared to give complete statements at the present time. 
The Nanking incident alone, when figures are brought to light of losses sustained by foreigners, will probably be at the head of the list, but isolated incidents are not being overlooked in the tabulation.

\section{I. M.'s Heavy Losses}

Some of the available facts show that the China Inland Mission, adhering strictly in the past to a policy of exacting no reparations, has been as hard hit as any. From Szechuan from which only scanty reports can be got at the present time we know that centres at Luchow have been looted, Wanhsien looted, and Paoning occupied by the military. Honan shows Yencheng looted; Kiangsu, three properties in Yangchow looted and occupied; Chinkiang occupied and looted.

In Kiangsi province (up to April 12) 24 stations of the C. I. M. had been affected, not including the Alliance China Mission; nine have been occupied by the military and in most cases damaged and looted; the hospital at Linkiang has been occupied by wounded soldiers and military; Loping station looted, after serious rioting and damage by the military and labour union.

Chêkiang centres of the C. I. M. have likewise been badly used and present reports are that seven properties have been damaged to greater or less extent, eight others looted and three chapels sealed. There have been 12 stations in this province previously occupied by the military, and one station at Yenchow bears the mark of having been 14 times oceupied. Political Labour Unions now have headquarters in eight C. I. M. centres in the province and occupation of four others are believed imminent following repeated threats.

\section{Chinese Christians Persecuted}

In all cases where Nationalist authorities have been in the ascendancy it is authoritatively stated that Chinese Christians are per- secuted when they attempt to worship.

In some places the local authorities "take over" schools and "run" them. It is almost impossible to speak of the taking over or the running without-a liberal sprinkling of inverted commas, so like a bad little boy's dream of attending school this process has been. Holidays exceed the wildest imaginations of the same bad little boy, student union meetings are given precedence to all merely scholastic duty, soldiers drill in the school premises and the authorities issue prolific accounts of their successes in administration.

To carry on with a few more instances, soldiers being quartered in all properties belonging to the Methodist Episcopal Church at Nanking, with Middle Schools being used as stables. All houses of this mission were looted, four of which were burned. The same applies to Chinkiang. In Wuhu, another chief centre of the mission, schools are closed. Kiukiang and Nanchang show churches full of soldiers and latest reports which, it is taken, do not apply to the Methodist mission alone show that Nationalist circles are beginning to press the idea of general confiscation of mission properties.

\section{Huge Sums in Damages}

It is estimated that the Women's Bible Training School at Nanking alone sustained $\$ 35,000$ damages, and other compilations of material damages by this mission show that about two months ago when Foochow institutions of the organization were gutted a total of between $\$ 50-60,000$ loss was involved.

The same conditions apply to the American Baptist Foreign Mission Society. Of the 65 schools, etc. of this mission, only those in Shaohsing, Hangchow and Ningpo in Chêkiang are "running." Other schools under Chinese supervision are at Suifu, Yachow, Kiating and Chengtu.

The American Church Mission, (American Episcopal) at Nan- 
king have finished a report of losses sustained by them in Nanking and in round numbers this is about $\$ 17,000$, accrued from the looting, down to the wordwork, of one boys' and one girls' school, three residences and a church.

\section{All Up the Yangtze}

At Yangchow, three residences have been looted and five buildings belonging to the mission occupied. Labour agitators are using the church, school and residence at Woosung for headquarters as they are at Kiangwan and Sungkiang which the military occupied. At Anking where one of the best equipped mission hospitals in this part of China is situated, soldiers are quartered in the hospital, and seven residences have been looted thoroughly. At Kiukiang, two churches, two boys' schools and two residences are all being occupied and from Nanchang comes the same report. At Wuchang "school is being kept" at Boone University, although less than one third of the students are there and soldiers drill on the grounds.

At Changsha buildings are all in the hands of the students' union, nor does this mission entertain any very high hopes about property at Ichang and Shasi.

South China reports have been filtering through with great regularity since the first days of Nationalist aggressiveness. Among the later ones is that the Canton Hospital belonging to the Presbyterian Mission is closed, owing to labour troubles and that the Kerr Hospital for the Insane belonging to the same mission is now being administered by the Southern government and that the sum of $\$ 1$ per year is paid as rent. Insane patients could neither leave the institution nor stay for awhile during the troubles, until the happy arrangement of paying $\$ 1$ a year rental was hit upon.

Hunan centres have suffered severely and reports from the
Northern Presbyterian Mission show that the Union Theological School at Changsha has been occupied by the military, Huchow occupied and the large hospital at Changteh closed owing to preposterous demands by the labour union.

\section{The Wrecked Missions of Nanking}

Detailed accounts of the losses sustained by the large missionary group resident in Nanking will be available in due course, as these are now being carefully prepared. An eye-witness who gave some idea of the clean-sweep of looting done by Nationalist forces there described the sights which he saw just before his evacuation on Friday of the fated week-end.

All Theological Seminary residences were looted, including those of two Chinese teachers as was the dormitory. The Library was sealed up, but later reports from Nanking show that the valuable books belonging to this institution were later sold by the pilfering soldiers who were quartered there. Near the Seminary, the Bible Teacher's Training: School's administration building and foreign teachers' residences were looted, while the dormitory was burned after mattresses soaked in oil had aided the conflagration. The Quakerage Chapel, next came under the observation of this informant, and it was seen that every movable object had been removed. The Y.W.C.A. Hostess House near at hand, the residence of a Nanking University professor, two houses belonging to the Stewart Evangelistic Fund, two Methodist houses and the house of the University builder next came into view, wrecked and looted. Looking up the road he saw the Hillcrest School burned, and in the same vicinity about a dozen other foreign missionary residences could be spied out, bearing all the marks of thorough looting. These details are perhaps more suitable for the official report which is being prepared than for generalization like 
the foregoing, but they all tend to show how widespread is the present epidemic of destroying mission property.

\section{Illusions and Stark Reality}

If there are any who harbour illusions that the present campaign of ruthlessness is one which will spend itself is due course, they have only to peruse newspaper accounts during the past two years to trace the steady advance under organized direction of the campaign.

"Outrages on American Missions," "Canton Strikers Generally AntiForeign," "Ban on Wuchow Hospital," "Mission Assailed," "Mission
Looted in the South," "The Merry Game of Confiscation" are some of the headlines which hundreds of such articles bear, and which represent so small a fraction of the destructive elements of the present time that one hesitates to introduce them when volumes of records pertaining ito missionary losses would be more to the point.

The fact also that many missionaries assume the attitude of ignoring the purely material aspects in sublimation of the ideal held by the Christian evangelist cannot be said to outweigh the obvious facts, the unjustifiable losses sustained throughout China as the result of the undisciplined Nationalist movement.

Reprinted from the "North-China Daily News," May 11, 1927.

\section{CHINESE PASTOR STONED TO DEATH}

\section{Suspected of Being an Imperialist by Yochow Farmers}

The following news items have the farmers took him and actually been received recently from $\mathrm{Hu}$ - stoned him to death. There has been nan by letter and telegram by some very bitter persecution in other a correspondent now in Shang- places, and some of the Christian hai:-

The Province of Hunan seems to be going through another very serious anti-Christian agitation, almost as bitter and better organized, in some places, than during the Christmas season last year. The most bitter and virulent form has taken place at 'Yochow, where a Christian Chinese Pastor, Cheng Tsochin, was stoned to death by farmers. The immediate cause of the outbreak by the rabble was the fact that Pastor Cheng was posting up some proclamations issued by the officials asking the people to protect mission property and Christian work. He was thus accused of being an Imperialist and seeking the leaders have had to flee. Pastor Cheng is the first martyr reported, others have been thrown into jail and molested in other ways.

\section{The Bitter Centre of Changsha}

Changsha is probably the next most bitter centre of this antiChristian movement. Siangtan which is not far from Changsha takes on pretty much the colour of the movement in Changsha. It is often remarked that "what happens in Changsha to-day will be sure to happen in Siangtan to-morrow or the next day." Most of the Mission property is occupied by soldiers or unions or schools; in protection of toleration treaties, and some cases written agreements are 
presented asking to borrow the property, but that is only a form. The Fuh-hsiang Girls school at Changsha was occupied first by soldiers and now by Seh Chuen students-some sort of student's organization. The beautiful campus has become a public place and as a recent letter naively says: "A public park without a manager."

The buildings of the Hunan Bible Institute have been occupied. The buildings of the United Evangelical Mission have been throughly ransacked, even the glass being removed from the windows. Several buildings on the campus of Yale in China have been taken over for use by a military academy and order is maintained. The residences are occupied by soldiers or "protected" by servants. All the trees on the campus which shaded adjoining farm land have been cut down by order of the Farmer's Union, which is now in control in Changsha.

\section{Position in Southern Hunan}

Southern Hunan has not been hit so hard by the recent stir up. There has been some looting and petty thieving of foreign residences at Hengchow, and one residence oceupied by soldiers and an organized three day anti-Christian programme was broken up without effecting much, though reports say that the situation is very uncertain there. The compradore of the Presbyterian Hospital had to flee for fear he would be asked to open up the drug and store rooms and hand out the stores and drugs on hand. The situation in Chenchow seems to be better than any of the above named places and Christian boarding schools are still carrying on there.

Many reports and rumours of killing and capturing the idle rich at Changsha were somewhat exaggerated, but some have been killed without trial, since this method did not produce the money, the new method is to throw them into gaol and persecute them until their money is produced. Many have tried to flee and some have got away. These refugees from Changsha are now being arrested by telegram on their arrival in Wuhan.

Even with all this terrorism, reports show that conditions are better than a few weeks back.

The German business community at Changsha is apparently not being disturbed. It has been reported that all the German China Inland Missionaries in Hunan have been ordered out and are to take up their residence in Hankow until conditions get better.

\section{Serious Period for the Church}

The Liang-Hu Synod of the Church of Christ in China met in Hankow on April 28 and was well attended. Only two presbyteries, Shenchow, Hunan, and Ichang, Hupeh, were not represented. One of the stirring incidents of this meeting was the memorial service held for the Martyred Pastor Cheng of Yochow, who was an officer of the Synod. The reports show that the Church of Christ in China is pasing through a very serious period, but all the Christian leaders are facing the future with courage and with hope. One letter said the organized Church may be crushed in this situation, but the zeal and faith of the believers in God and their new found Saviour cannot be crushed by such persecutions.

A very interesting social event that took place was the celebration of the marriage ceremony of a newly ordained Pastor of Hengchow, Hunan, before the whole Synod.

\section{Helplessness of Officials}

Reports have come from Liling, Siangtan and other places that foreigners private houses have been entered and much personal property stolen or destroyed. The officials are helpless, and there is little hope of saving any private personal property as long as the present lawlessness prevails. 


\title{
C. I. M. PREMISES AT ANKING
}

\section{Illegal Seizure of Mission Property by Kuomin- tang Government}

\author{
FroM OUR OWN CORRESPONDENT
}

\begin{abstract}
Anking, Mar. 21. soon as they can get ready.
General Chiang K'ai-shek arrived No attempts have yet been General Chiang Kaicher to occupy the American Mission, and no injurious conduct headquarters here.

The Political Bureau of the 33rd Army has occupied the China Inland Mission premises, so that the foreigners of the C. I. M.- those in the training school and other workers-are forced to leave as of any sort has come to our notice. Students have quite thoroughly placarded the American houses with their proclamations of "Down with English Imperialism" and "Long live the Kuomintang," "To the uniting of China and the Kuomintang," etc.
\end{abstract}

Reprinted from the "North-China Daily News," May 12, 1927.

\section{ORGY OF MISSION LOOTING}

\section{Vandalism by Kuangtung and Kuangsi Mobs: 30 Buildings Wrecked in a Month}

\section{From OUR OWN CORRESPONDENT}

Hongkong, Apr. 25.

Recently a lawless rabble raided and looted the chapel and residence of the Reformed Presbyterian Mission in Dosing, Kuangtung. This was followed by the forcible taking over of the premises by the Peasants Union, who turned the buildings into offices of the union for "the enforcement of law and order." Two influential Christian workers put in a protest against what they considered unlawful acts, and as a result both of them were arrested and cast into gaol. Efforts now are being made to secure the release of the two men, but their crime--protesting against the looting of 1 spring rains which have now set the chapel and forcible occupation by the union-is considered a serious offence in these days when Lawlessness is on the throne and Righteousness must bow and be silent.

Following the looting of valuable mission property belonging to three societies in the city of Kueilin, towards the end of March, the wave of lawlessness spread northward and ten chapels were looted and more or less damaged by groups of hooligans stirred up by the students. In most of the buildings the furniture was more or less destroyed, while one of the chapels had the roof partly taken off in order that the 
in might do greater damage to the building.

It is useless to protest against these acts of vandalism. When protests are made, the officials profes: extreme sorrow for the action and always promise protection, and this protection usually is granted to the wrecked buildings, but presently another outrage is perpetrated in a neighbouring town, and again protests, apologies and promises follow each other like a merry wheel of fortune. One becomes tired of trying to deal with a so-called government who secretly encourage lawlessness and whose word is but "a scrap of paper" that cannot be relied on the least unless there is some gain to them included in the bargain. During the past 30 days there have been outbreaks of lawlessness in Kuangsi during which time about 30 mission buildings have been attacked and more or less damaged, some practically destroyed, and yet no one has been arrested, no one has been punished, and the whole attitude of the governing classes is such as to encourage the ignorant rabble to carry on their work of destruction and pillage whenever they feel like making a new attack.

\section{Reprinted from the "North-China Daily News," May 23, 1927.}

\section{THE RED REGIME IN CHINA}

Prophecy is always rash in feeling against Red Russian inChina, but there is every reasort to believe that within the next few days the last traces of the thoroughly evil régime at Hankow will be wiped out, the last of the eloquent Soviet hirelings will have fled with his loot, and the net result of Bolshevist effort and a vast expenditure of Russian money will be a wholesome fear in all political camps of association with the Soviet agents that will rule them out of all native conferences for years to come. The cost of the experiment that has been made by the Cantonese "Nationalists" to conquer China with Soviet support, in exchange for which they gave the Red destroyers a free hand with the mob and assisted them in their assault upon their country's economic structure, has been so enormous and the miseries of the people so terrible, that there has been a genuine revulsion of fluence throughout China. No Chinese military or political leader has the courage to oppose himself to such intense public feeling once it is made clearly manifest, no matter what personal advantages may be offered him, so that if Hankow falls in the burst of fireworks and welter of blood that now seems inevitable, those who still have Soviet affiliations will be in the greatest possible haste to free themselves of the Red taint. Feng Yu-hsiang is not one to adhere to a losing cause and whatever Chiang Kai-shek's plans are for regaining control of the "Nationalist" movement with Soviet support on new terms, a sufficiently spectacular extirpation of Communism and the would-be Communists from Hupeh and Hunan can be relied upon to prompt an abrupt change of heart in Nanking that will be a genuine shock to Moscow. 
The white Russians among us would get a serious hearing. expect that reverberations of the fall of Hankow will be heard far beyond China's frontiers and even go so far as to assume that the failure of the Soviet's plans in China will be the beginning of the end of Bolshevism in Russia. The wish here is certainly father to the thought, but there is no reason to doubt that a nation-wide repudiation of Soviet influence in China will have its effect in Russia. American labour has denounced Bolshevism over and over again in the least compromising comments upon Soviet policy that we have ever seen in print. That Red propaganda is discredited in Great Britain is sufficiently evident from the fact that the Government has had the courage to raid Soviet premises in London and that British labour, even of the most radical kind, has voiced no serious protest. Every energetic Red effort on the Continent has inspired such a disastrous reaction that burnt Bolshevist fingers are now encased in gloves whenever there is occasion to handle anything European. Asia has been for several years their one promising hunting ground. Asiatic trade has no little bearing upon Occidental employment and prosperity, and since the war Asia has been restless, to say the least. China, with all her postrevolutionary turmoil and her uncertainty as to her eventual destiny, not to mention her traditional anti-foreign bias, was undoubtedly the most promising medium through which to commence a demoralization of Asia that would reduce the West economically to a point where the insidious Red missionary

China has been from the beginning a temperamental and discouraging subject on which to pratice, but Moscow has outdone herself in both patience and generosity, and if ever a wily suitor deserved to lead a bride to the altar, the Soviet has earned the right to China's hand. China's fickleness, of which Karakhan used to complain and against which Borodin is now said to be inveighing, is therefore, likely to inspire more than ordinary disgust and despondency in the supreme dictatorship in Moscow and may quite possibly prompt a reaction against that dictatorship within the bounds of the U.S.S.R. Further than this, failure in China may divert Soviet attention from the assiduous efforts which she has made for years to promote friction between the various hostile factions of White Russians abroad through which the Soviet has always warded off the most serious menaces against its survival in Russia.

The world at large has undoubtedly envisaged those possibilities and wil? find satisfaction in them if it becomes sufficiently clear that China has finally disowned and rejected Communism and Red patronage, but the effect that this will have upon Occidental policy in this country is not so certain and may not afford the foreign communities in China much reason for jubilation. In spite of overwhelming evidence, piled up in the British, American, Japanese and French capitals over a period of at least five years, it has only been within the past few weeks that our Governments have most reluctantly confessed 
that there has been a streak of Communism running through China's "Nationalism" and that there has been active Soviet inspiration behind the anti-foreign movement in China. The very real danger is that, if this Soviet influence is now eliminated and is then denounced by all the various factions, the Home Governments will seize upon the opportunity to announce that Chinese "Nationalism" is now purged of malign alien influence and that the time has come for further concessions to Chinese "aspirations", more patient conciliation and more negotiation with the various leaders looking to a surrender of foreign rights as defined in the "noxious unequal treaties." We all know hereor we should know if we do not -that the "Nationalist" military movement into the Yangtze Valley owes its cohesion, its virility and its popularity to Russian direction of both military operations and propaganda. We know that the movement began to disintegrate as Chiang Kai-shek and others began to defy Soviet instructions and take their bits in their teeth, and we can assume with certainty that the complete elimination of Russian influence will mean the descent of all the southern provinces into a state of anarchy, in which anti-foreignism will be the one and only prevailing keynote. We have to fear this will not be understood abroad until more fatal ventures upon conciliation have been made, more fatal negotiations mooted, more precedents of surrender established and more losses of foreign prestige, lives and wealth suffered. The difficulty of making this clear to the Occidental peoples is much greater than the difficulty of persuading them of the malevolent influence of the Soviet upon an Oriental people and will require a supreme effort on the part of the Occidental communities in China if we are not to be sacrificed on the "Nationalist" altar.

Reprinted from "North-China Daily News," May 31, 1927.

\section{MISSION CEMETERY AT CHUCHOW DESECRATED}

\section{Missions Looted by Nationalist Soldiers and Occupied by Troops and Labour Unions}

\section{From OUR OWN CORRESPONDENT}

Hangchow, May 28. the province of Fukien en route to The Chientang River is again the the war zone. Boats are being scene of great activity. Large seized for transportation purposes military forces are pouring in from and coolies are impressed into the 
service. The border town of Changshan is also alive with military activity. The premises of the China Inland Mission are still in occupation by the soldiers and Labour Unions. Recently the chapel has been used as a recruiting centre.

In the eastern section, around the county of Yungkang, the political situation is reported as being more quiescent, and the same, more or less throughout the county of Kinhua. In Lanchi, the Labour Union still hold on to the house belonging to the missionaries of the China Inland Mission. Over the main gateway the sign "Lanchi Labour Bureau Headquarters" looms out in bold prominence. The school premises are also in their possession and used as offices. The same tale may be repeated in respect to the Church and School premises of Yenchow.

\section{Boxer Outrage Recalled}

A report has just come through from Chuchow, one stage below the town of Changshan, which makes the blood run cold. It may be remembered this was the only town in Chêkiang which carried out that blood-thirsty decree of the late Empress Dowager-"Kill the foreigner." In the Boxer year a company of C. I. M. missionaries were cruelly done to death some were butchered right in front of the yamên gates which were closed upon them as they sought a place of refuge from the howling mob. As part compensation for this barbarous massacre a piece of rising ground, within the city limits, was made over by the officials to the C. I. M. for a burial place. Within the shades of this walled enclosure the remains of this brave missionary band have reposed. Now comes the message which it is hoped cannot possibly be true. The source of the news is authoritative and reads:-

"In visiting the cemetery, I found the 12 graves, together with the ornamental memorial arches, have all been broken by soldiers of the Nationalist Army and the people. The white and green marble slabs have been destroyed and even the bones within the graves have been dug out and scattered over the ground.

"The bamboos, peach, plum and every kind of tree have been cut down and all the windows of the cemetery house have been broken.

"This evil work was perpetrated during the three days of May 1719. On May 20 a military official came and caused the caretaker to collect the bones, dig a hole in the ground and bury them: then they were covered over with earth. For doing this work the official gave a remuneration of 20 cents-small money. As to the Church, this had been officially sealed by the magistrate. On the advent of the Nationalist soldiers, however, the seals were broken and they forcibly took possession.

"The sin and lawless actions of these soldiers and people have reached the full for they not only oppose God but destroy the morality of man."

\section{Missions Looted}

The mission stations of Changshan, Chuchow, Lanchi and Yenchow have not only been taken over by the military and Labour Unions but, under their régime, the belongings of the missionaries have been thoroughly looted and despoiled. It is feared the station at Kinhua has shared the same fate. 


\section{SEMI-NUDE GIRLS ARE FOLLOWING COMMUNIST ARMY}

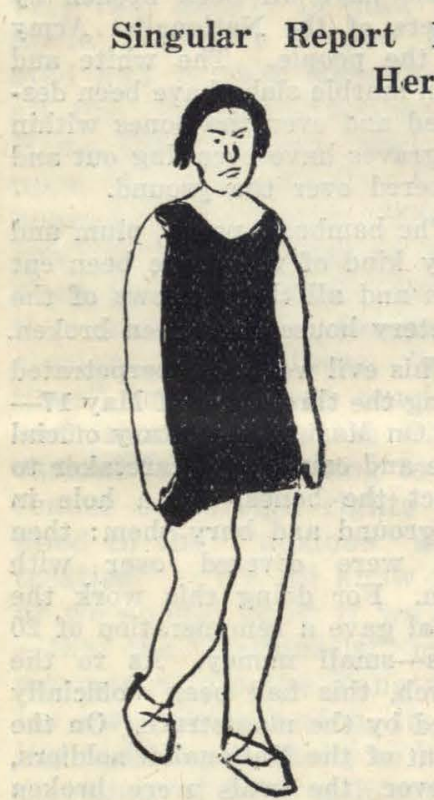

This is a reproduction of the picture drawn by the Chinese Christian worker and enclosed in the Chinese letter to his missionary pastor. Below the picture were the following Chinese characters:

這樣的裝式無是可憐哪

(This is the pattern of dress; really

it is pitiable.)

It was announced in the Shanghai Missionary Association Prayer Meeting, held last night in the Missions Building, that a letter had been received by the leader of the meeting from his station in Hunan to-day, stating that an official proclamation had been issued requiring all girls over sixteen years of age to be married at once, and the proclamation states that if any girls remain unmarried by a certain time (presumably within a month), the officials will provide husbands for them.

The statement was also made that a letter had been received by a missionary from another Communist ruled province, written to him by one of the Chinese Christian workers connected with his church, telling of the arrival of between ten and twenty thousand their district with over two hund- I the street."

red young women who are wearing no clothing except one upper garment coming down only a few inches below their hips.

A drawing made with a Chinese pen was enclosed in the Chinese letter, showing the style of the garments.

The following is a literal translation of the paragraph of the letter dealing with this item: "To-night (May 1st) one of our Christians brought the news from a nearby city (which is named in the letter, but which the missionary desires not to be published for obvious reasons), that there had arrived upwards of twenty thousand soldiers and that there were over two hundred young women with them, between the ages of eighteen and twenty years, who wore no trousers, but only wore one top garment 


\section{"NAKED BODY PROCESSION"}

\section{Poster on Nationalist Bulletin Boards}

Translation of POSter ExhibitED ON SEveral Notice BoARds, OUTSIDE ADMINISTRATION BUILDINGS OF THE NATIONALIST Government IN HANKOW. (TRANSLATION BY REV. $\mathrm{K}-$, Missionary IN Hankow.)

\section{"CHINESE WOMEN'S ASSOCIATION"}

\section{NAKED BODY PROCESSION.}

"All ladies and girls: You must know that the women in general have been depressed by the corrupt militarists and have suffered their cruel treatment for a long time. Now the Nationalist Revolutionary troops being successful in their public services, they are getting rid of militarists of this kind, and send out our women free.
The Women's Association suggests having a NAKED BODY PROCESSION on the first of May, thus promoting the principle of freedom.

Any women wishing to enter into the NAKED BODY PROCESSION -an examination of the body is necessary. The choice will fall on those having snow-white bodies and perfect breasts."

It has been reported in several papers that such a procession did take place in Hankow. It is also said that a similar procession was held in Nanchang. THOSE WHO ARE FAMILIAR WITH THE MODESTY OF CHINESE WOMEN, during the past centuries, require no further or more conclusive proof of the pernicious influence of Russian Communism than the above poster.

Reprinted from "North-China Daily News," May 3, 1927.

\section{AMERICAN'S TESTIMONY}

\section{Re Outrage Upon His Sister by Nationalist Soldier at Nanking}

To the Editor of the

"North-China DaIly News."

SIR,-Mr. Carroll Lunt's defence of American Policy in China is naturally welcomed by the unenlightened Americans possessing extreme patriotism.

If Mr. Lunt's wife was in my sister's position he would probably refrain from defending anything but drastic action by his Government in China. MY SISTER, I WOULD MENTION, WAS ONE
OF THE UNFORTUNATE VICTIMS OF THE NANKING INSULTS AND HAS HAD TO UNDERGO TREATMENT FOR A CERTAIN UNPARDONABLE OFFENCE COMMITTED BY A NATIONALIST SOLDIER AT THE TIME OF EVACUATION.

If America withdraws from her duty to the Nanking Americans it will be to her lasting disgrace.

I am, etc., TRUE AMERICAN.

Shanghai, May 2, 1927. 


\section{AMERICAN POLICY AND THE NATIONALISTS}

To the Editor of the

"NoRTh-China DaILy News."

SIR,-It has become evident that, unless the American Government acts in a firmer manner than it seems likely to act just now vis dे vis the "Nationalists" all Americans attempting to enter "Nationalist" territory will continue to be treated as outlaws, both in their persons and their property. Unless something real is done to prove that America intends to protect Amerieans, no American goods can be delivered into the interior and no American will ever be able to live in the least security outside of the foreign sections of Shanghai. The moment has come when we must take united action or pack up what things we have left if any and go to America. All Americans remaining in Shanghai must unite immediately in an appeal to the President and people of the United States to face the real facts and deal with all sections of the "Nationalists' Governments" according to these facts and without any more pretences. Unless we do this our Missions will be ruined and many Americans who are engaged in small businesses will be impoverished beyond hope of recovery. We all know now that the promises of this or that "Nationalist" to protect Americans are worth much less than nothing and are meant only to befuddle the public in America.

I am writing this letter to propose that the American Chamber of Commerce, as being already organized, draw up an appeal to our country to "protect us in our lawful occupations and pursuits" and to do it now. I am certain that almost all missionaries, who have not already been obliged to leave for home, will sign such an appeal.
The point of the appeal should be to inform the American people that many of them have been absolutely deceived by the "slick" propagandists for the "Nationalists" and to remind them that we Americans came to China trusting in the honour of our nation to protect us and that now all of those, who lived there, have been hounded out of "Nationalist" China, some of us in the roughest sort of fashion to a small area here in Shanghai which is defended by foreign troops and that the goods and physical equipment of most of us, who have had to flee here, have been plundered by soldiers of the "Nationalist" Party, whose commanders seem with one hand to be writing fair-sounding promises for the people in America to read and with the other hand orders to their soldiers to plunder and mistreat Americans.

Such a petition as I am proposing could be drawn up and eopies placed at convenient places for signatures.

We must act at once or it will be too late.

Enclosing my card,

I am, etc.,

\section{. VETERAN AMERICAN Missionary.}

Shanghai, May 1, 1927.

P. S. In order to avoid delay I am emboldened to append the draft of a cablegram, which I hope will meet the approval of Americans. I expect to leave a copy of this draft with the officers of the American Chamber of Commerce on Monday morning, May 2. I think that each person who signs it will be glad to make a contribution towards sending it according to his means. The draft of the proposed cablegram follows:- 
(Suggested form of cablegram.)

TO THE PRESIDENT AND PEOPLE OF THE UNITED STATES:

We, the undersigned Americans, gathered in Shanghai, desire respectfully to call your attention to certain facts regarding China and to ask for action that will benefit the Chinese people primarily and the whole international position generally as well as ourselves.

We realize how difficult it is for our fellow-countrymen at home to understand the facts of the situation in China. This, we believe, is due to adroit propaganda that has been conducted over a period of years, to make the so-called Nationalist government appear as the patriotic administration of an awakened and enlightened China. The government, already broken into factions, is no such thing. The facts wholly belie the propagandists' statements: and the assurances and agreements of one faction and another have repeatedly proven valueless.

We came to China trusting that our nation would protect us in our "lawful occupations and pursuits." We, merchants and missionaries, have invested our lives, work and property under this belief. These treaties must be lived up to until new ones can be negotiated. If you allow the so-called Nationalist government to abrogate these treaties, as has been done in practice, you will not only betray us, but you will contribute to and encourage world anarchy and disorder.

We are convinced by abundant evidence that the Moscow Soviet is largely responsible for the present anarchy in the Yangtze Valley. Chinese agitators, trained in Moscow in large numbers and paid by the Soviet, have been at work in China for several years. The good of any section of the Chinese people is, of course, no part of Mosesw's programme. Moscow's real object is to attack and destroy civilization, directly and indirectly, in any way that it can.

Western Powers have pledged themselves to revise the treaties when there shall be any responsible government for China. The revision of the treaties with Siam, which has already taken place, is notable evidence of their willingness to do this voluntarily.

The so-called Nationalist government in no way answers to the requirements of a reasonable government. We, who were not already in Shanghai, have been forced to take refuge here, not only because we were summoned out by consular instructions, but because conditions had actually become dangerous, through the disorders arising in many places, reaching their climax in the looting, murdering and raping in Nanking. Law abiding Chinese are being treated in the same way. With the exception of less than a hundred Americans, who are remaining in Hankow, in the hope of holding on to the shreds of their institutions and businesses, we have been compelled to desert the entire Yangtze Valley. The men remaining in Hankow are able to do so only because they can flee to ships in the River within a few minutes.

Much, if not almost all mission property-churches, schools, hospitals and residences-has been seized and looted by Nationalist soldiers and in some cases burned, this action being most wanton as there are no such Chinese institutions to replace them. No American can enter Nationalist territory except with the certainty that he will be treated as an outlaw. This certainty is so great that there are no Americans there. Many of us are merchants of small means, who will be ruined unless the United States government protects us in our rights.

No constructive government has been organized, but the destruction perpetrated has added to the widespread disorder and disaster that 
already existed. The lives and properties of Chinese are no safer at the hands of the Bolshevized militarists of the South than they were under the brigand-like warlords of the North. The whole region is in chaos, both politically and economically, and the people will be rapidly reduced to a state of absolute misery and starvation.

The failure of the various factions of the Nationalist government to keep promises or to maintain order has convinced us that no negotiation will be of any use. As for America, there are but two or three courses possible:

1. The first is for the American government to evacuate us, thus acknowledging frankly that it does not intend to stand by its obligations to protect its citizens.

2. Another course, equally shameful, would be for Americans to continue to depend on Great Britain for protection, as we are doing here in Shanghai, and to try to return to some of the ports along the Yangtze, after the British have established some order in these ports. That would, however, not solve the problem for a great number of us whose posts of duty are in the interior and away from the ports. We have no concessions of our own, but wherever British concessions exist, our American consulates are established within them. If it had not been for the foresight of Great Britain (later supported by a detachment of our marines and others) in sending soldiers to Shanghai, a ghastly tragedy on a large scale would undoubtedly have been enacted here.

3. The desirable course to follow would be for the United States government to act in accordance with the facts which it has in the reports of its consular officials and take active measures in cooperation with Great Britain and other Powers, looking towards the protection of Americans in China, and to co-operate in any and all constructive measures looking towards the establishment of law and order.

We are truly friendly to China and are convinced that the law abiding element and the plain people among the Chinese would welcome such a move and that the results would be to the mutual benefit of China and the rest of the world.

\section{RODNEY GILBERT'S AFFIDAVIT}

\section{Re Foreign Woman Raped Nine Times by Nationalist Soldiers in Nanking}

[This letter and affidavit were not published in the N.-C. D. N. because of newspaper practice of not giving publicity to matters in which members of the staff are personally concerned].

To the Editor of the

\section{"North-China DAILY NeWs."}

SIR,-As certain parties are declaring that there is no evidence of a single case of indecent attacks on foreign women in Nanking and are getting this published widely in the press of both America and
Britain, I was requested by a number of business men to secure some definite evidence, if possible, for publication, as well as for forwarding to Washington and London. Mr. Rodney Gilbert has kindly written me the following letter and gone to the American Consulate and taken oath as to the 
statement by the doctor reported therein, and, although under ordinary circumstances, you would not be willing to give publicity to such harrowing atrocities, I hope you will share this document with your readers at this time.

Having consulted with several Nanking missionaries and others, including several ladies, who were greatly shocked to read this affidavit, I can assure you that all of them felt that this should be published in the press and given the widest possible publicity.

The consular officials at the Anerican Consulate assured me that this affidavit would be sent to Washington at once. A copy was also sent to the British Consulate General for the purpose of forwarding to London.

Obviously, no lady is willing to have her name known and no doctor can reveal names or medical secrets, but I think if it becomes known that only as much as is made known regarding facts in this letter, without the name of the doctor or the patient, is useful to the governments, probably others will come forward with information which can be certified by reliable persons. For example, perhaps "True American" who wrote in your issue of May 3 about his sister suffering "a certain unpardonable offence committed by a Nationalist soldier at the time of the evacuation of Nanking," might be willing to meet $\mathrm{Mr}$. Gilbert or some one else and give confidential information, which could be sworn to for the benefit of officials and the public, provided he was assured that his name or his sister's would not be made known.

A British merchant showed me a letter from a member of Parliament in which it was stated that he had been shown the consular records from Nanking on file in the Foreign Office in London, and that there was no record of a case of rape at Nanking, and pointing out that it was difficult for government officials at home to prove that there were cases of this kind if there was no definite evidence in the files in London. Of course, a certified copy of Mr. Gilbert's affidavit is now being forwarded to London.

Especially as you are being charged with exaggeration in stating that you have refrained from printing certain "unprintable facts" in connection with the Nanking outrage, I hope you will see your way clear to the publication of this remarkable document, upon the urgent request of several of those most concerned.

I am, etc.,

Edgar E. Strother.

Shanghai, June 6, 1927.

North-China Building,

Shanghai, China, June 1, 1927.

Dear Mr. Strother,-In response to your enquiry after tangible evidence of OUTRAGES UPON AMERICAN AND OTHER FOREIGN WOMEN BY THE SOUTHERN SOLDIERY at Nanking, March 24, I am sorry to have to tell you that, like many others who interviewed scores of refugees after the looting of the foreign houses, I have never had a direct confession from any woman that she had been raped nor have I been able to come into possession of any documentary evidence. Indirect testimony has, however, been abundant and I am fully convinced in my own mind that I know of ten or twelve cases of rape, quite apart from the well known cases in which women admitted that outrages had been attempted upon them. Of these ten or twelve cases, I am only sufficiently certain of my sources of information in one instance to SWEAR that a woman was actually outraged. In the course of my futile search for 
direct evidence I inally appealed to a doctor who, to my knowledge, was attending several women from Nanking in a local hospital and asked whether he could or could not tell me of a bone fide case in which a foreign woman had actually been outraged. At the time he would not commit himself, but several days later he sent for me and said that he felt that I was entitled to know, since I had published details of several alleged cases of rape under atrocious circumstances, that my reports were not exaggerated. $\mathrm{He}$, therefore, assured me on his word that ONE OF HIS PATIENTS HAD BEEN STRIPPED NAKED BY THE SOLDIERY, THROWN ON THE GROUND, RAPED NINE TIMES BEFORE SHE LOST CONSCIOUSNESS AND WAS SUBSEQUENTLY FOUND COMPLETELY BURIED IN HUMAN EXCREMENT. Her assailants had taken all the commodes in the house in which they had found her and emptied them over her.

I naturally had to promise not to reveal the doctor's name if I ever gave this publicity and I was not told the woman's name, BUT I CAN CHEERFULLY TAKE OATH THAT THE STORY AS I HAVE RELATED IT CAME TO ME IN THIS WAY and I can assure you that the medical man who gave me this single case is not only one of the most reliable men in Shanghai but is particularly level headed-anything but hysterical. You are free to use this letter in any way that appeals to your own good judgement.

\section{Yours very truly, RODNEY GILBERT.}

I, Rodney Gilbert, a citizen of the United States of America, for the time being on the editorial staff of "The North-China Daily News," a daily newspaper published in Shanghai, China, being first duly sworn, on oath depose and say that the letter of which the foregoing is a true and correct copy was written by me to Mr. Edgar E. Strother, General Secretary of the China Christian Endeavour Union, and that the statement of the doctor given therein is an accurate report of his words to me.

RODNEY GILBERT.

Sworn to before me, this $3 r d$ day of June, in the year of our Lord one thousand nine hundred twenty seven, at Shanghai, China.

Henry S. Waterman,

Consul of the United States of America at Shanghai, China.

American Consulate-General, ShanghaI, China.

AMERICAN

CONSULAR SERVICE $\$ 2$

FEE STAMP 